\title{
Ethanol Extract of Tripterygium wilfordii Hook. f. Induces G0/G1 Phase Arrest and Apoptosis in Human Leukemia HL-60 Cells Through c-Myc and Mitochondria-Dependent Caspase Signaling Pathways
}

\author{
Chung-Jen Chiang et al.* \\ Department of Medical Laboratory Science and Biotechnology, \\ China Medical University, Taichung, \\ Taiwan
}

\section{Introduction}

Tripterygium wilfordii Hook. f. is a traditional Chinese herb (Murphy, 2006; Qiu et al., 2003). The extract of Tripterygium wilfordii Hook. f. has been widely applied to the treatment of immune-related diseases, such as rheumatoid arthritis (RA), nephritis, and systemic lupus erythematosus (SLE) (Chang et al., 1999; Wang et al., 2000). Extracts of Tripterygium wilfordii Hook. f. have been shown to inhibit lymphocyte proliferation induced by mitogentic stimulation in-vitro (Wu et al., 2003). Triptolide (PG490, one of the most active components in Tripterygium wilfordii Hook. f. extract, possesses immunosuppressive, anti-inflammatory and anti-fertility actions in vivo and in vitro (Zhao et al., 2005; Leuenroth et al., 2005). Many reports have demonstrated that triptolide has anti-proliferate activity against L1210, U937, K562, HL60, and P388 leukemia cells (Lou et al., 2004; Chan et al., 2001; Wei et al., 1991). However, the cellular and molecular mechanisms underlying mediating Tripterygium wilfordii Hook. f.-induced differentiation and/or apoptosis in leukemia cells have not been well studied.

Leukemia is a malignant disease characterized by uncontrolled cellular growth and disrupted differentiation of hematopoietic stem cells (Lichtman et al., 2005; O'Hare et al., 2006). Chemotherapy can be effective in certain types of leukemia, but in cases in which it

\footnotetext{
* Jai-Sing Yang1, Yun-Peng Chao², Li-Jen Lin³ Wen-Wen Huang4, Jing-Gung Chung4, Shu-Fen Peng', Chi-Cheng Lu ${ }^{5}$, Jo-Hua Chiang ${ }^{5}$, Shu-Ren Pai ${ }^{4}$ and Minoru Tsuzuki ${ }^{6}, 7$

${ }^{1}$ Department of Pharmacology, China Medical University, Taichung, Taiwan

${ }^{2}$ Department of Chemical Engineering, Feng Chia University, Taichung, Taiwan

${ }^{3}$ School of Chinese Medicine, China Medical University, Taichung, Taiwan

${ }^{4}$ Department of Biological Science and Technology, China Medical University, Taichung, Taiwan

${ }^{5}$ Department of Life Sciences, National Chung Hsing University, Taichung, Taiwan

${ }^{6}$ Nihon Pharmaceutical University, Saitama, Japan

${ }^{7}$ Tsuzuki Institute for Traditional Medicine China Medical University, Taichung, Taiwan
} 
is not effective additional therapeutic strategies are needed. (Faderl et al., 2005; Frankfurt et al., 2006; ter Bals et al., 2005). Several compounds are capable of inducing the differentiation of leukemia cells into mature cells in vitro, and differentiation therapy has been shown to be an effective approach for treating leukemia (Altucci et al., 2004; Altucci et al., 2005; Takahashi et al., 2002). Human promyelocytic leukemia HL-60 cells and mouse monocytic leukemia WEHI-3 cells are commonly used to study various properties of leukemia cell proliferation and differentiation in vitro (Lin et al., 2006; Abe et al., 1987). Differentiation of HL-60 is induced into granulocytes by dimethyl sulfoxide (DMSO) and all-trans retinoic acid (ATRA), and into monocytic-like cells by phorbol ester (TPA) and 1,25-dihydroxy-vitamin D3 (Tsiftsoglou et al., 2003). In HL-60 cells, differentiation is induce-specific and is characterized by agents to differentiated is a marked increase in the proportion of G0/G1 cells (Yen et al., 2006), and the modulation of cyclin/CDK (Horie et al., 2004; Wang et al., 1996; Barrera et al., 2004; Pizzimenti et al., 1999; Kumakura et al., 1996).

In hematopoietic cells, apoptosis can be coupled to terminal differentiation of myeloid progenitor (Yazdanparast et al., 2005; Samudio et al., 2005). Cells undergoing apoptosis have observable morphology changes expressed as nuclear condensation, DNA fragmentation, and compact packaging of the cellular debris into apoptotic bodies (Fleischer et al., 2006; Bohm et al., 2006). The delivery and performance of apoptotic signals requires a coordinated cascade of caspase activation and action. The initiator caspases include caspase- 8 in Fasinduced apoptosis, and caspase-9, the activation of which is triggered by cytochrome $c$ release from mitochondria in response to various stimuli. Those caspases can directly activate downstream effectors of caspase- $3,-6$, and -7 , which cleave death substrates, such as poly(ADP-ribose) polymerase (PARP) (Christophe et al., 2006; Lucken et al., 2005; Lockshin et al., 2005).

In this study, we investigated the cytotoxic effects of ethanol extract of Tripterygium wilfordii Hook. f. (ETW) on the promotion of cell cycle arrest and apoptosis in HL-60 cells. Our results indicated that ETW effectively induces both G0/G1 phase arrest and apoptosis of HL-60 cells in vitro. The mechanisms governing ETW-induced G0/G1 phase arrest included down regulation of cyclin E, Bcl-2 and Bax, and -triggered apoptosis through caspase-9, caspase- 8 and caspase-3-dependent pathways.

\section{Materials and methods}

\subsection{Chemicals and reagents}

EDTA, Propidium iodide (PI), RNase A, Tris-HCl, Tritox X-100, Tween 20 and Proteinase K were obtained from Sigma Chemical Co. (St.Louis, MO, USA). RPMI-1640 medium, fetal bovine serum (FBS), and L-glutamine, penicillin/streptomycin were obtained from Gibco BRL Co. (Grand Island, NY, USA). The caspase-3, caspase- 8 and caspase- 9 activity assay kits were bought from R\&D Systems, Inc. (Minneapolis, MN, USA)

\subsection{Ethanol Tripterygium wilfordii Hook. f. (ETW) extraction}

Dried and powdered plant materials were subjected to continuous ethanol extraction in a Soxhlet extractor with absolute ethanol for $72 \mathrm{~h}$. The ethanol extract was collected and 
concentrated by vacuum distillation. The extract was evaporated to dryness and reconstituted in ethanol before experiment.

\subsection{Cell culture and viability assay}

The human promyelocytic leukemia cell line (HL-60) was obtained from the Culture Collection and Research Center (CCRC, Taiwan, R.O.C.), originally from the American Type Culture Collection (ATCC, USA). Cells were cultured in RPMI-1640 culture medium (Gibco/Life Technologies, Taipei, Taiwan) supplemented with 10\% heated-inactive fetal bovine serum (Gibco/Life Technologies), $2 \mathrm{mM}$ L-glutamine, penicillin (100 units/ml), and streptomycin $(100 \mu \mathrm{g} / \mathrm{ml})$ (Gibco/Life Technologies) and incubated at $37^{\circ} \mathrm{C}$ in humidified $5 \%$ CO2 atmosphere.

For viability analysis, $2.5 \times 10^{5}$ cells/well were seeded in 24-well culture plates. ETW was added to each well and the plates were incubated at $37^{\circ} \mathrm{C}$ for 24,48 and $72 \mathrm{~h}$. Cell viability was estimated by a propidium iodide (PI) incorporation assay and flow cytometry (FACS CaliburTM, Becton Dickinson) analysis (Aouacheria et al., 2002).

\subsection{Cell cycle analysis}

Cells were incubated with 50, 100 or $200 \mu \mathrm{g} / \mathrm{mL}$ of ETW for 0,24 or $48 \mathrm{~h}$. After treatment, cells were washed with phosphate-buffered saline (PBS) twice. The cells were re-suspended in hypotonic PI solution ( $0.1 \%$ sodium citrate, $0.1 \%$ Triton $X-100$, and $50 \mu \mathrm{g} / \mathrm{ml}$ propidium iodide), and then cellular DNA content was determined by flow cytometry (Kamikubo et al., 2003).

\subsection{Western blotting analysis}

Total protein was prepared with protein lysising buffer (PRO-PREPTM protein extraction solution, iNtRON Biotechnology, Seongnam, Gyeonggi-Do, Korea). The concentration of protein was determined by the Bradford method using the Bio-Rad protein assay dye reagent. The lysates containing $40 \mu \mathrm{g}$ of protein were separated by SDS-PAGE and transferred onto PVDF membrane. Nonspecific binding sites were blocked with $5 \%$ non-fat milk in PBST buffer (0.05\% Triton X-100 in PBS) for $1 \mathrm{~h}$. The PVDF membrane was incubated overnight at $4^{\circ} \mathrm{C}$ with specific primary antibodies against cyclin D1, cyclin E, Bcl2, and $\alpha$-tubulin (Santa Cruz Biotechnology, Inc., Santa Cruz, CA, USA). After being washed with PBST buffer, the membrane was incubated with horseradish peroxidase (HRP)conjugated secondary antibodies (Santa Cruz). Immunoreactive proteins were detected using a Western Blotting Chemiluminescence Reagent Plus kit (NENTM Life Science) and exposed to Chemiluminescence films (Choi et al., 2003).

\subsection{Caspase activities assays}

Cells were collected in lysis buffer ( $50 \mathrm{mM}$ Tris-HCl, $1 \mathrm{mM}$ EDTA, $10 \mathrm{mM}$ EGTA, $10 \mathrm{mM}$ digitonin and $2 \mathrm{mM}$ DTT) and placed on ice for $10 \mathrm{~min}$. The lysates were centrifuged at $15,800 \mathrm{~g}$ at $4^{\circ} \mathrm{C}$ for $10 \mathrm{~min}$. Cell lysates (50 $\mathrm{gg}$ of protein) were incubated with caspase $-3,-9$, and -8 specific substrates (Ac-DEVD-pNA, Ac-LEHD-pNA, and Ac-IETD-pNA) with reaction buffer in a 96-well plate at $37^{\circ} \mathrm{C}$ for $1 \mathrm{~h}$. The caspase activity was determined by measuring OD405 of the released pNA (An et al., 2004). 


\subsection{Statistical analysis}

Results are presented as mean \pm S.D. Differences between the different treatment groups, which consisted of matched samples, were assessed by the Student's $t$-test. A p value of less than 0.05 was considered to be significant.

\section{Results}

\subsection{Effects of ETW on cell viability in HL-60 and WEHI-3 cells}

We treated HL-60 cells with ETW at the concentrations of 0, 50, 100 and $200 \mu \mathrm{g} / \mathrm{ml}$. The number of viable cells was counted by a PI exclusion method 0,24 and $48 \mathrm{~h}$ later. As shown in Fig. 1, ETW exerted a dose- and time-dependent loss of cell membrane integrity and viability in HL-60 cells.

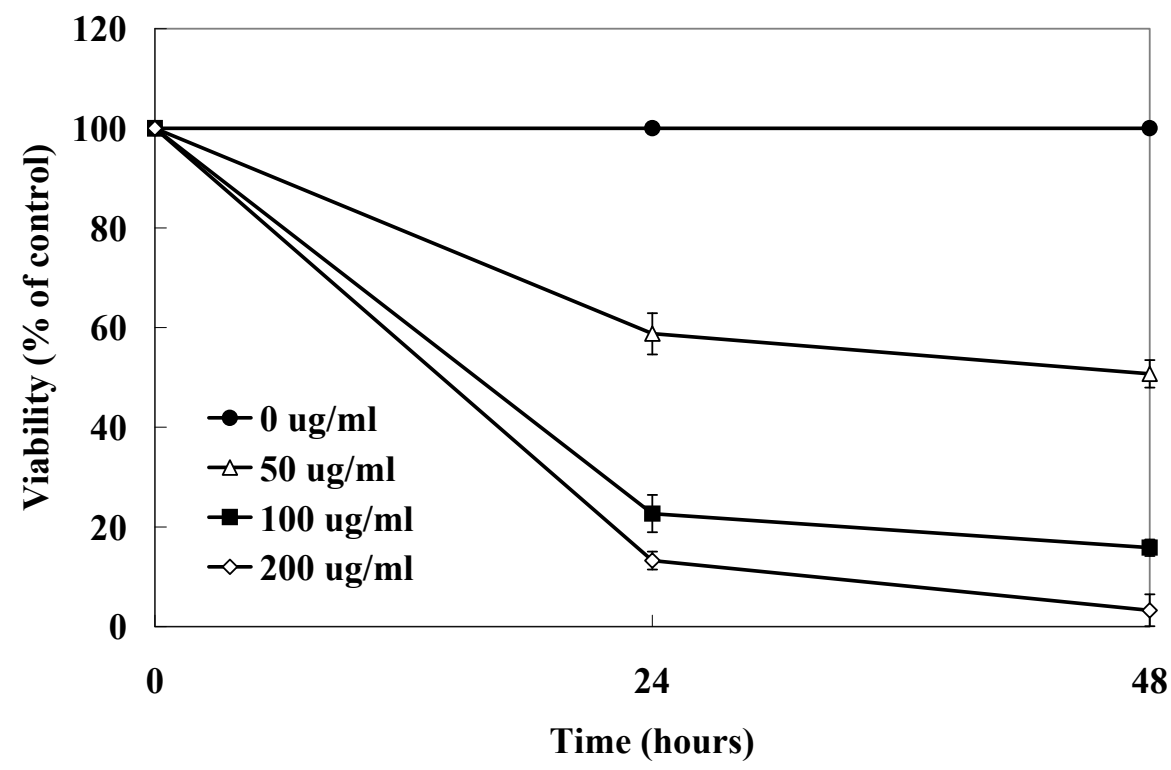

Fig. 1. Effects of cell viability in ETW treated HL-60 cells. Cells were treated with various concentrations of ETW for indicated duration. Viable cells were measured by PI exclusion and immediately analyzed by flow cytometry. The percentage of cell viability was calculated as a ratio between drug-treated cells and control cells. Each value represents mean \pm S.D. from three independent experiments

\subsection{Effects of ETW on cell cycle progression in HL-60 cells}

To investigate the mechanisms by which ETW induced cytotoxicity effect in HL-60 cells, we cultured cells for various time periods with $100 \mu \mathrm{g} / \mathrm{ml}$ ETW and analyzed DNA content by flow cytometry. Cell cycle analysis showed that ETW induced a prominent G0/G1 population arrest in HL-60 cells (Fig. 2.). In addition, $100 \mu \mathrm{g} / \mathrm{ml}$ of ETW increased the subG0/G1 nuclei population in HL-60 cells in a time-dependent manner (Fig. 2.). 


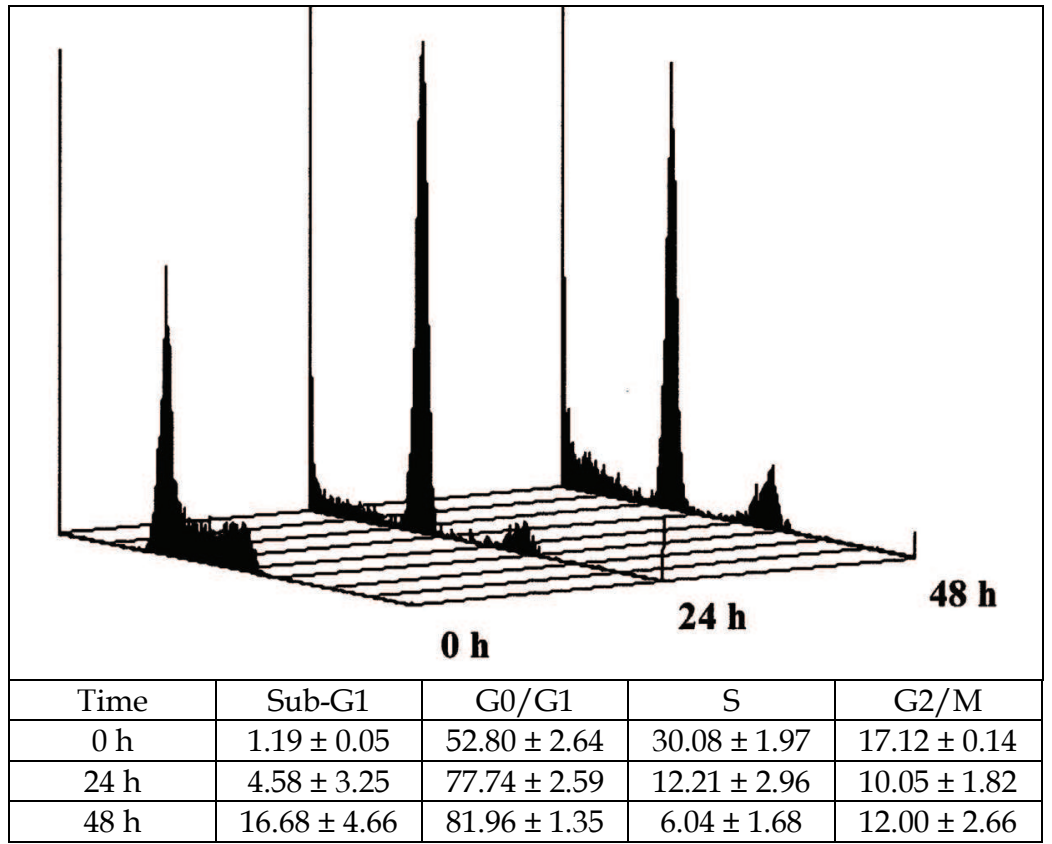

Fig. 2. Cell cycle progression on HL-60 cells after treated with ETW. Cells were treated with ETW for the indicated incubation times, then stained for DNA with PI, and analyzed for cell cycle progression or apoptosis by flow cytometry. Cell cycle analysis showed that ETW induced a prominent G0/G1 population arrest and apoptosis in HL-60 cells. Each value represents mean \pm S.D. from three independent experiments

\subsection{Effects of ETW on cyclin D1, cyclin E, Bcl-2 and c-Myc proteins expression in HL-60 cells}

To better understand how ETW induces G0/G1 arrest, we investigated the protein expressions of cyclin D1 and cyclin E. After treatment with $100 \mu \mathrm{g} / \mathrm{ml}$ of ETW, there was a marked increase in protein levels of cyclin D1 and a marked decrease in cyclin E (Fig. 3A and 3B.) We also examined the expression levels of Bcl-2 and c-Myc protein. As shown in Fig. 3C and 3D, Bcl-2 and c-Myc protein levels decreased in HL-60 cells relative to controls. Our results suggest that ETW induces G0/G1 arrest and apoptosis in HL-60 cells by regulating cyclin D1, cyclin E, Bcl-2 and c-Myc protein expression.

\subsection{ETW induced apoptosis is mediated by the activations of caspase-9, caspase-8 and caspase-3}

Activation of caspase plays a key role in the induction of apoptosis. We used a fluorogenic enzymatic assay to detect activated caspase- 9 , caspase- 8 and caspase- 3 in ETW-treated HL60 cells. Both caspase- 9 and caspase- 3 activities increased $24 \mathrm{~h}$ after ETW treatment and caspase-8 activities increased $48 \mathrm{~h}$ after ETW treatment (Fig. 4). Our results suggest that ETW-induced apoptosis is mediated through the activation of caspase-9, caspase- 3 and then caspase-8. 


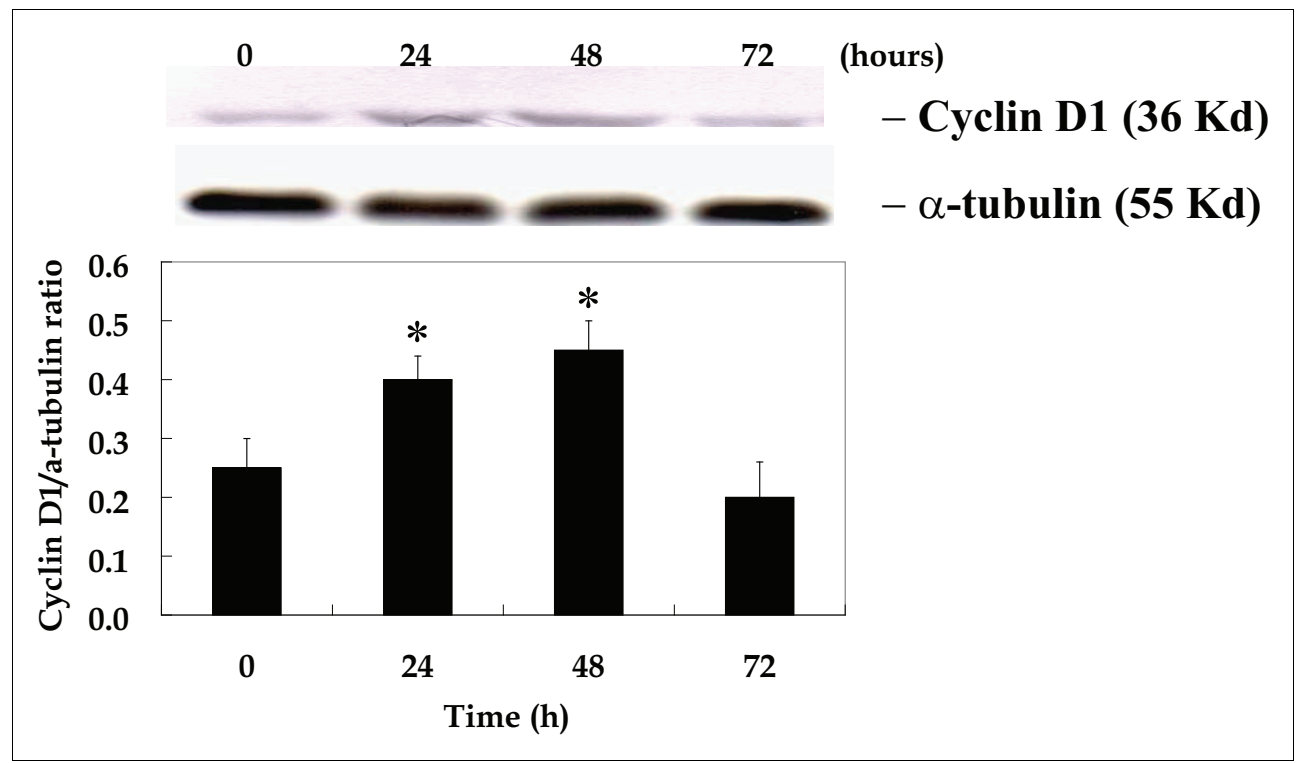

(a)

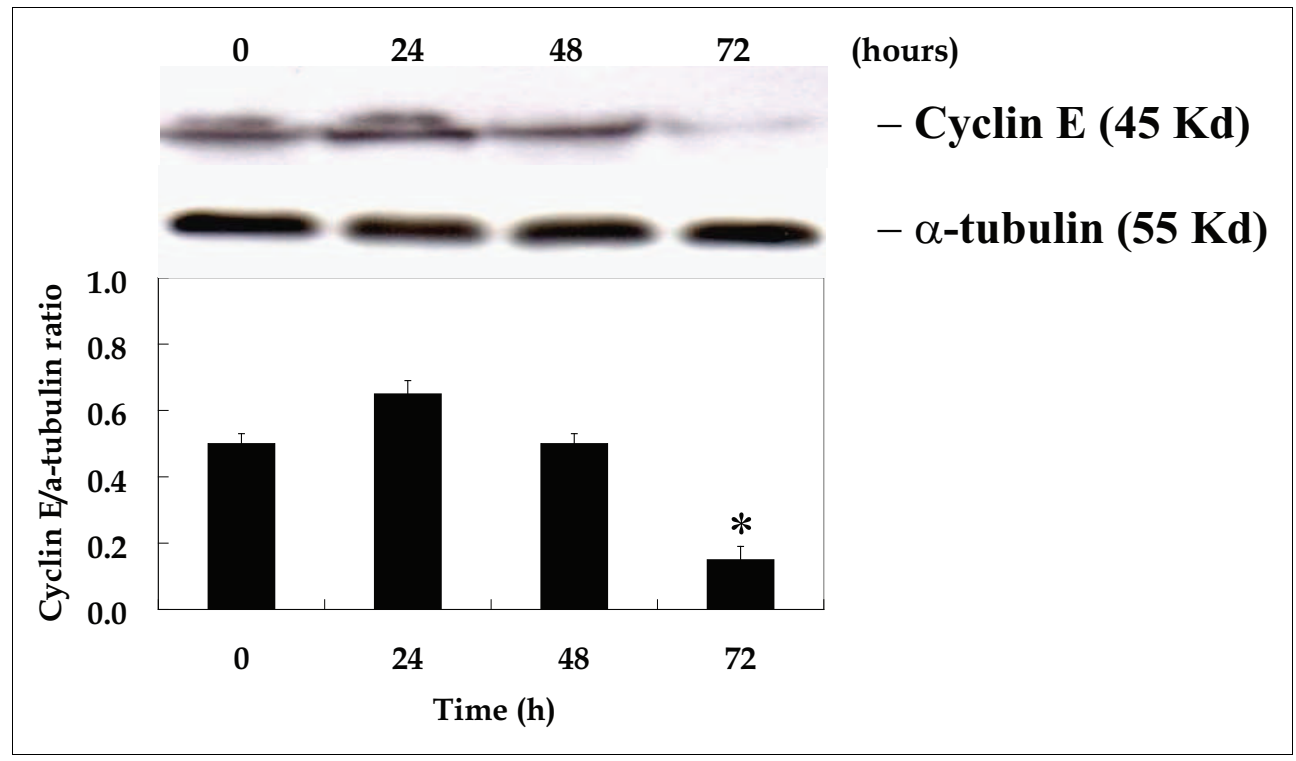

(b) 


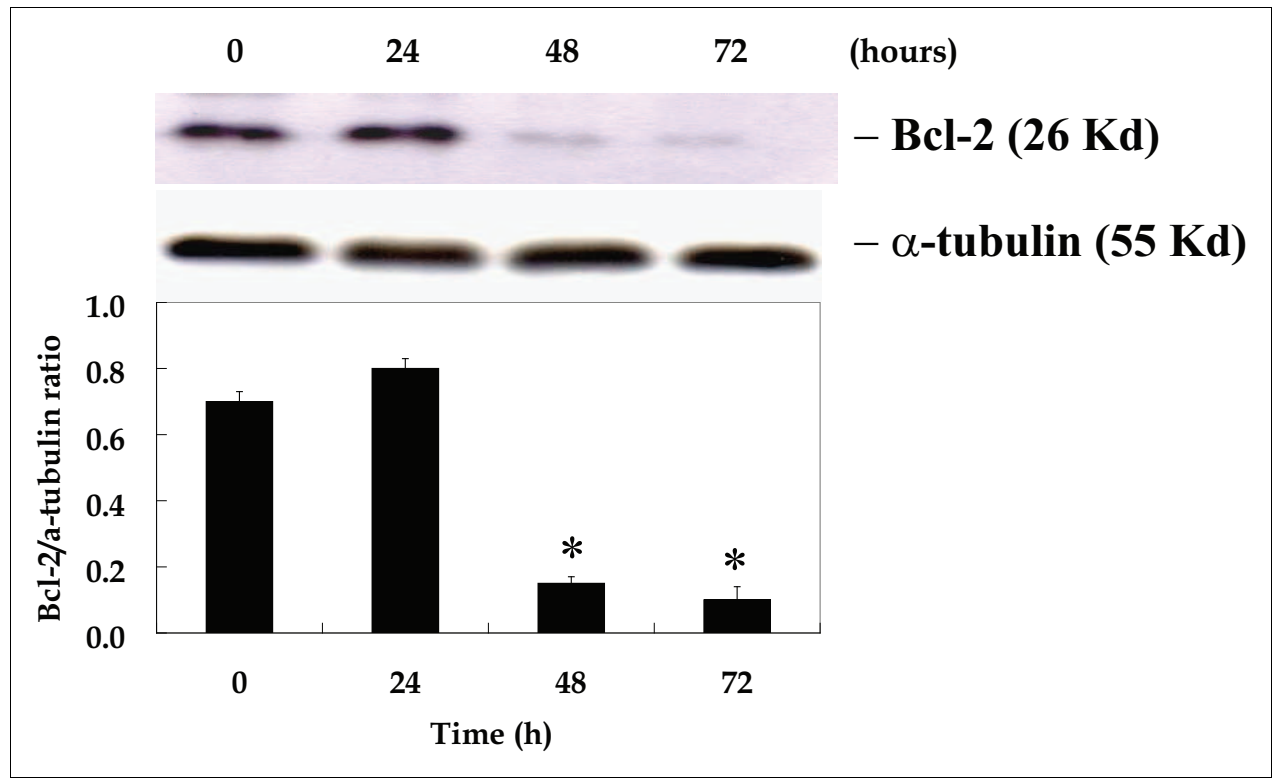

(c)

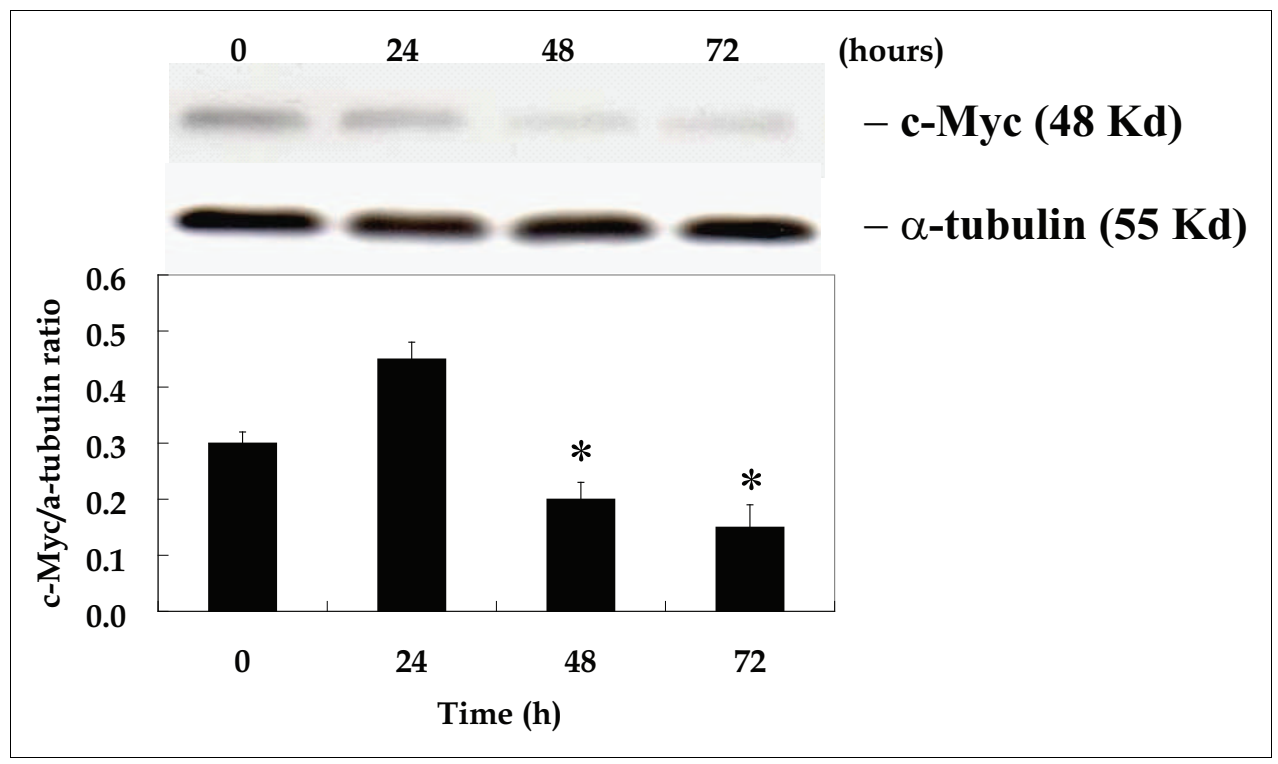

(d)

Fig. 3. Representative Western blotting showing changes on the levels of (A) cyclin D1, (B) cyclin E, (C) Bcl-2 and (D) c-Myc in HL-60 cells after exposure to ETW (100 $\mu \mathrm{g} / \mathrm{ml})$. Cells were treated with ETW for the indicated incubation times then total protein were prepared and determined as described in Materials and Methods 


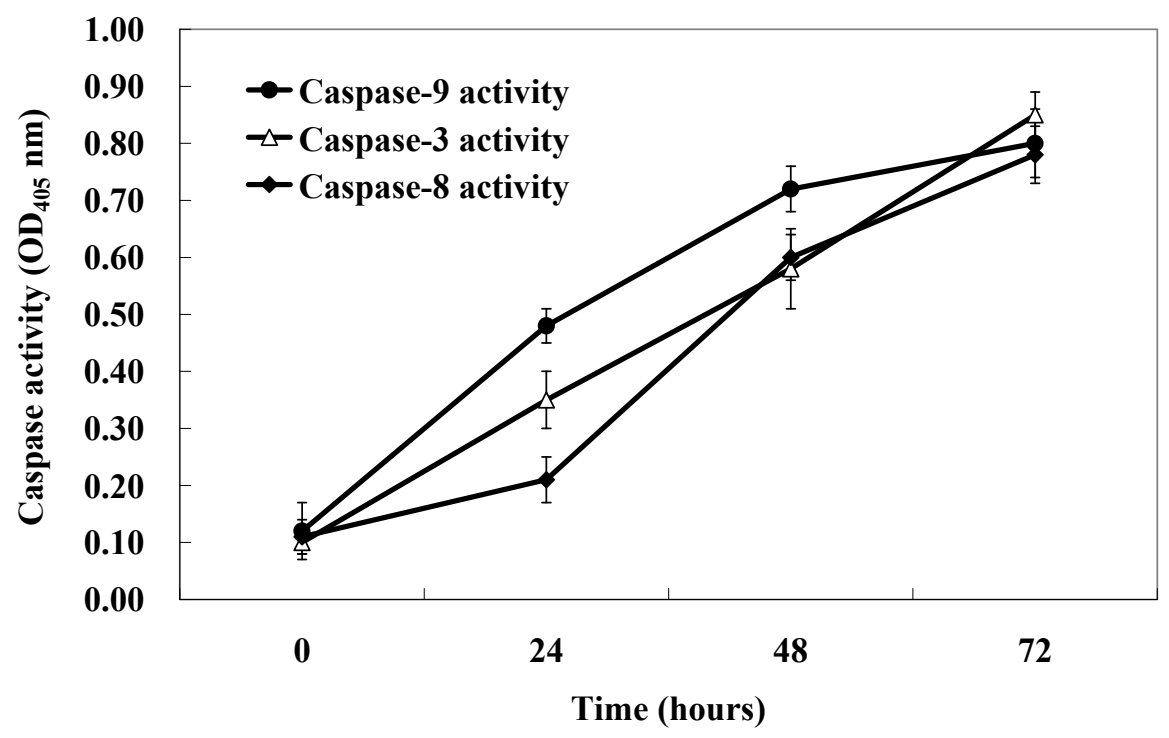

Fig. 4. Effects of ETW induced apoptosis on HL-60 cells by caspases-9, -8 and -3 activities.

For caspase activity analysis, aliquots of total cell extracts were incubated with caspases-3, -9 and -8 specific substrates, respectively (Ac-DEVD-pNA, Ac-LEHD-pNA and Ac-IETD-pNA). The release of pNA was measured at $405 \mathrm{~nm}$ by a spectrophotometer

\section{Discussion}

Tripterygium wilfordii Hook. f. (TWHF) is used to treat inflammatory and immune-related diseases. Triptolide, a diterpenoid triepoxide extracted from the TWHF, exerts antitumorigenic actions against leukemia cells. In Differentiation -inducing activity study, some triterpene aglycones and Betulinic acid (pentacyclic triterpene) showed differentiationinducing activity and against human acute promyelocytic leukemia HL-60 cells (Poon, 2004; Umehara et al., 1992). The preclinical laboratory work of identification and testing of potential anti-leukemia agents is designed for three categories: inhibition of cell proliferation, promotion of cell cycle arrest and induction of apoptosis. In the present study, we demonstrated that ETW induces cell cycle arrest and apoptosis in HL-60 cells. Hence, we suggest that ETW is a potent Chinese herb in HL-60 leukemia cells. However, it remains unclear whether ETW effectively induces the elimination of premalignant cells apoptosis in vivo.

The effects of ETW on HL-60 cells were associated with a specific disruption of cell cycle events and an induction of G0/G1 arrest. Our results show that ETW led to a loss of cell viability in a dose- and time-dependent manner (Fig. 1). Our study demonstrated that G1 cyclins (cyclin D1 and E) were regulated of HL-60 cells induced by ETW. A recent investigation of leukemia cell differentiation agent-induced differentiation of HL-60 leukemia cells has suggested that TPA to differentiate along the monocyte/macrophage lineage up-regulated of cyclin D1, and all-trans retinoic acid (ATRA) to differentiate along the Granulocyte lineage down-regulated cyclin E expression (Wang et al., 1996; Barrera et 
al., 2004; Pizzimenti et al., 1999). Thus, it could be suggested that the regulation of cyclin D1 and $\mathrm{E}$ as well as CDK2 might anticipate in part the early events in differentiation in ETWtreated HL-60 cells. Our studies found that ETW reduced the level of Bcl-2 and c-Myc in a time-dependent manner. Regulation of the relative levels of Bcl-2 and c-Myc may play an important role in modulating the susceptibility of cells to differentiation ( $\mathrm{Li}$ et al., 2004; $\mathrm{Wu}$ et al., 2002). Previous studies have demonstrated that HL-60 cells exhibited an overexpression of $\mathrm{Bcl}-2$ and $\mathrm{c}-\mathrm{Myc}$ proto-oncogene and that alteration of cellular oncogenes occur during the differentiation of HL-60 cells (Kumakura et al., 1996). Within myeloid lineage, Bcl-2 is over-expressed in early myeloid precursors but under-expressed or absent in matured myeloid cells and neutrophils (Gazitt et al., 2001; Blagosklonny et al., 1996).

Apoptosis is an evolutionarily conserved process that regulates development and homeostasis, and defects in the mechanisms that regulate cell death are implicated in both tumor genesis and multidrug resistance. Two distinct pathways for apoptosis have been defined, namely the death-receptor pathway and mitochondria pathway (Bohm et al., 2006; Christophe et al., 2006; Lucken et al., 2005; Lockshin et al., 2005). The signal transmitted to the mitochondria pathway causes the release of cytochrome $c$ into cytosol. We analyzed apoptosis induction in ETW-treated HL-60 cells by measuring the accumulation of sub-G1 nuclei overtime. We observed the induction of caspase- 9 and caspase- 8 at $24 \mathrm{~h}$ of treatment, and caspase- 3 activities at $48 \mathrm{~h}$ of treatment before the onset of DNA fragmentation at $72 \mathrm{~h}$ treatment by at ETW (Fig. 4). Furthermore, we detected loss of mitochondria membrane potential $(\Delta \Psi \mathrm{m})$ in ETW-treated HL-60 cells and release of mitochondrial cytochrome $\mathrm{c}$ to cytosol after $18 \mathrm{~h}$ of treatment (data not shown). Recent investigation of triptolide-induced apoptosis of U937 cells has suggested that induced caspase-3 activation and downregulation of the caspase inhibitory protein, XIAP, are involved in this apoptotic process (Choi et al., 2003). Recent reports suggest that DNA damage results in onset of mitochondrial permeability transition, which plays a major role in the apoptotic processes (Choi et al., 2003). A common step in apoptosis involves the loss of mitochondrial membrane potential resulting in increased generation of reactive oxygen species (ROS) from the mitochondrial respiratory chain. Our results suggest that ETW-induced apoptosis is mediated through the loss of mitochondria membrane potential and activation of caspase cascades by activated caspase- $9,-8$ and caspase- 3 in a cytochrome c-dependent manner.

In summary, our results show that ETW induced G0/G1 arrest of HL-60 leukemia cells by regulating the protein expression of cyclin D1, cyclin E, Bcl-2 and c-Myc, and that it induced apoptosis in HL-60 cells by activating caspase-9, caspase- 8 and caspase-3. ETW might, therefore, be an alternative cancer therapy in treatment of leukemia patients.

\section{References}

Abe J., Morikawa M., Miyamoto K., Kaiho S., Fukushima M., Miyaura C., Abe E., Suda T., Nishii Y., 1987. Synthetic analogues of vitamin D3 with an oxygen atom in the side chain skeleton. A trial of the development of vitamin D compounds which exhibit potent differentiation-inducing activity without inducing hypercalcemia. FEBS Letters 226, 58-62.

Altucci L., Rossin A., Hirsch O., Nebbioso A., Vitoux D., Wilhelm E., Guidez F., De Simone M., Schiavone EM., Grimwade D., Zelent A., de The H., Gronemeyer H., 2005. Rexinoid-triggered differentiation and tumor-selective apoptosis of acute myeloid 
leukemia by protein kinase A-mediated desubordination of retinoid $\mathrm{X}$ receptor. Cancer Research 65, 8754-8765.

Altucci L., Wilhelm E., Gronemeyer H., 2004. Leukemia: beneficial actions of retinoids and rexinoids. International Journal of Biochemistry \& Cell Biology 36, 178-182.

An WW., Wang MW., Tashiro S., Onodera S., Ikejima T., 2004. Norcantharidin induces human melanoma A375-S2 cell apoptosis through mitochondrial and caspase pathways. Journal of Korean Medical Science 19, 560-566.

Aouacheria A., Neel B., Bouaziz Z., Dominique R., Walchshofer N., Paris J., Fillion H., Gillet G., 2002. Carbazolequinone induction of caspase-dependent cell death in Srcoverexpressing cells. Biochemical Pharmacology 64, 1605-1616.

Barrera G., Pizzimenti S., Dianzani MU., 2004. 4-hydroxynonenal and regulation of cell cycle: effects on the pRb/E2F pathway. Free Radical Biology \& Medicine 37, 597606.

Blagosklonny MV., Alvarez M., Fojo A., Neckers LM., 1996. bcl-2 protein downregulation is not required for differentiation of multidrug resistant HL60 leukemia cells. Leukemia Research 20, 101-7.

Bohm I., Traber F., Block W., Schild H., 2006. Molecular imaging of apoptosis and necrosis - basic principles of cell biology and use in oncology. Rofo: Fortschritte auf dem Gebiete der Rontgenstrahlen und der Nuklearmedizin 178, 263-271.

Brown G., Drayson MT., Durham J., Toellner KM., Hughes PJ., Choudhry MA., Taylor DR., Bird R., Michell RH., 2002. HL60 cells halted in G1 or S phase differentiate normally. Experimental Cell Research 281, 28-38.

Chan EW., Cheng SC., Sin FW., Xie Y., 2001. Triptolide induced cytotoxic effects on human promyelocytic leukemia, $\mathrm{T}$ cell lymphoma and human hepatocellular carcinoma cell lines. Toxicology Letters. 122, 81-7.

Chang DM., Kuo SY., Lai JH., Chang ML., 1999. Effects of anti-rheumatic herbal medicines on cellular adhesion molecules. Annals of the Rheumatic Diseases 58, 366-371.

Choi YJ., Kim TG., Kim YH., Lee SH., Kwon YK., Suh SI,. Park JW., Kwon TK., 2003. Immunosuppressant PG490 (triptolide) induces apoptosis through the activation of caspase-3 and down-regulation of XIAP in U937 cells. Biochemical Pharmacology 66, 273-80.

Christophe M., Nicolas S., 2006. Mitochondria: a target for neuroprotective interventions in cerebral ischemia-reperfusion. Current Pharmaceutical Design 12, 739-57.

Faderl SJ., Keating MJ., 2005. Treatment of chronic lymphocytic leukemia. Current Hematology Reports 4, 31-38.

Fleischer A., Ghadiri A., Dessauge F., Duhamel M., Rebollo MP., Alvarez-Franco F., Rebollo A., 2006. Modulating apoptosis as a target for effective therapy. Molecular Immunology 43, 1065-1079.

Frankfurt O., Tallman MS., 2006. Strategies for the treatment of acute promyelocytic leukemia. Journal of the National Comprehensive Cancer Network 4, 37-50.

Gazitt Y., Reddy SV., Alcantara O., Yang J., Boldt DH., 2001. A new molecular role for iron in regulation of cell cycling and differentiation of HL-60 human leukemia cells: iron is required for transcription of p21(WAF1/CIP1) in cells induced by phorbol myristate acetate. Journal of Cellular Physiology 187, 124-135.

Hickey EJ., Raje RR., Reid VE., Gross SM., Ray SD., 2001. Diclofenac induced in vivo nephrotoxicity may involve oxidative stress-mediated massive genomic DNA 
fragmentation and apoptotic cell death. Free Radical Biology \& Medicine 31, 139152.

Ho LJ., Lai JH., 2004. Chinese herbs as immunomodulators and potential disease-modifying antirheumatic drugs in autoimmune disorders. Current Drug Metabolism 5, 181192 ,

Horie N., Mori T., Asada H., Ishikawa A., Johnston PG., Takeishi K., 2004. Implication of CDK inhibitors p21 and p27 in the differentiation of HL-60 cells. Biological \& Pharmaceutical Bulletin 27, 992-997.

Kamikubo Y., Takaori-Kondo A., Uchiyama T., Hori T., 2003. Inhibition of cell growth by conditional expression of $\mathrm{kpm}$, a human homologue of Drosophila warts/lats tumor suppressor. Journal of Biological Chemistry 278, 17609-17614.

Kumakura S., Ishikura H., Tsumura H., Iwata Y., Endo J., Kobayashi S., 1996. c-Myc and Bcl2 protein expression during the induction of apoptosis and differentiation in TNF alpha-treated HL-60 cells. Leukemia \& Lymphoma 23, 383-394.

Leuenroth SJ., Crews CM., 2005. Studies on calcium dependence reveal multiple modes of action for triptolide. Chemistry \& Biology 12, 1259-1268.

Li CY., Zhan YQ., Xu CW., Xu WX., Wang SY., Lv J., Zhou Y., Yue PB., Chen B., Yang XM., 2004. EDAG regulates the proliferation and differentiation of hematopoietic cells and resists cell apoptosis through the activation of nuclear factor-kappa B. Cell Death \& Differentiation 11, 1299-1308.

Lichtman MA., Segel GB., 2005. Uncommon phenotypes of acute myelogenous leukemia: basophilic, mast cell, eosinophilic, and myeloid dendritic cell subtypes: a review. Blood Cells Molecules \& Diseases 35, 370-383.

Lin CC., Kao ST., Chen GW., Ho HC., Chung JG., 2006. Apoptosis of human leukemia HL-60 cells and murine leukemia WEHI-3 cells induced by berberine through the activation of caspase-3. Anticancer Research 26, 227-242.

Lockshin RA., 2005. Programmed cell death: history and future of a concept. Journal de la Societe de Biologie 199, 169-173.

Lou YJ., Jin J., 2004. Triptolide down-regulates bcr-abl expression and induces apoptosis in chronic myelogenous leukemia cells. Leukemia \& Lymphoma 45, 373-376.

Lucken Ardjomande S., Montessuit S., Martinou JC., 2005. Changes in the outer mitochondrial membranes during apoptosis. Journal de la Societe de Biologie 199, 207-210.

Murphy, 2006. Rachel Chinese antirheumatic remedy for the treatment of SLE. Nature Clinical Practice Rheumatology 2, 180-181.

O'Hare T., Corbin AS., Druker BJ., 2006. Targeted CML therapy: controlling drug resistance, seeking cure. Current Opinion in Genetics \& Development 16, 92-99.

Peng X., Zhao Y., Liang X., Wu L., Cui S., Guo A., Wang W., 2006. Assessing the quality of RCTs on the effect of beta-elemene, one ingredient of a Chinese herb, against malignant tumors. Contemporary Clinical Trials 27, 70-82.

Pizzimenti S., Barrera G., Dianzani MU., Brusselbach S., 1999. Inhibition of D1, D2, and Acyclin expression in HL-60 cells by the lipid peroxydation product 4hydroxynonenal. Free Radical Biology \& Medicine 26, 1578-1586.

Poon KH., Zhang J., Wang C., Tse AK., Wan CK., Fong WF., 2004. Betulinic acid enhances 1,25-dihydroxyvitamin D3-induced differentiation in human HL-60 promyelocytic leukemia cells. Anti-Cancer Drugs 15, 619-624. 
Qian SZ., 1987. Tripterygium wilfordii, a Chinese herb effective in male fertility regulation. Contraception 36, 335-345.

Qiu Daoming, Kao PN., 2003. Immunosuppressive and Anti-Inflammatory Mechanisms of Triptolide, the Principal Active Diterpenoid from the Chinese Medicinal Herb Tripterygium wilfordii Hook. f. Drugs in R \& D 4, 1-18.

Samudio I., Konopleva M., Safe S., McQueen T., Andreeff M., 2005. Guggulsterones induce apoptosis and differentiation in acute myeloid leukemia: identification of isomerspecific antileukemic activities of the pregnadienedione structure. Molecular Cancer Therapeutics 4, 1982-1992.

Takahashi N., 2002. Induction of cell differentiation and development of new anticancer drugs. Journal of the Pharmaceutical Society of Japan. 122, 547-563.

Ter BE., Kaspers GJ., 2005. Treatment of childhood acute myeloid leukemia. Expert Review of Anticancer Therapy 5, 917-929.

Tsiftsoglou AS., Pappas IS., Vizirianakis IS., 2003. Mechanisms involved in the induced differentiation of leukemia cells. Pharmacology \& Therapeutics 100, 257-290.

Umehara K., Takagi R., Kuroyanagi M., Ueno A., Taki T., Chen YJ., 1992. Studies on differentiation-inducing activities of triterpenes. Chemical \& Pharmaceutical Bulletin. 40, 401-405.

Veselska R., Zitterbart K., Auer J., Neradil J., 2004. Differentiation of HL-60 myeloid leukemia cells induced by all-trans retinoic acid is enhanced in combination with caffeic acid. International Journal of Molecular Medicine 14, 305-310.

Wang J., Xu R., Jin RL., Chen ZQ., Fidler JM., 2000. Immuno-supperssive activity of the Chinese medicinal plant Tripterygium wilfordii Hook.: I. prolongation of rat cardiac and renal allograft survival by the PG27 extract and Immunosuppressive Synergy in Combination Therapy with Cyclosporine. Transplantation 70, 447-455.

Wang QM., Jones JB., Studzinski GP., 1996. Cyclin-dependent kinase inhibitor p27 as a mediator of the G1-S phase block induced by 1,25-dihydroxyvitamin D3 in HL60 cells. Cancer Research 56, 264-267.

Wei YS., Adachi I., 1991. Inhibitory effect of triptolide on colony formation of breast and stomach cancer cell lines. Zhongguo Yao Li Xue Bao/Acta Pharmacologica Sinica 12, 406-410.

Wu LD., Chen YZ., Li NN., Wu Y., 2002. Study on telomerase activity and expression of hTERT, c-myc and bcl-2 during terminal differentiation of HL-60 cells induced by retinoic acid. Zhongguo Shi Yan Xue Ye Xue Za Zhi 10, 395-399.

Wu Y., Wang Y., Zhong C., Li Y., Li X., Sun B., 2003. The suppressive effect of triptolide on experimental autoimmune uveoretinitis by down-regulating Th1-type response. International Immunopharmacology 3, 1457-1465.

Yazdanparast R., Moosavi MA., Mahdavi M., Sanati MH., 2005. 3-Hydrogenkwadaphnin from Dendrostellera lessertii induces differentiation and apoptosis in HL-60 cells. Planta Medica 71, 1112-1117.

Yen A., Varvayanis S., Smith JL., Lamkin TJ., 2006. Retinoic acid induces expression of SLP76: expression with c-FMS enhances ERK activation and retinoic acid-induced differentiation G0/G1 arrest of HL-60 cells. European Journal of Cell Biology 85, 117-132.

Zhao YF., Zhai WL., Zhang SJ., Chen XP., 2005. Protection effect of triptolide to liver injury in rats with severe acute pancreatitis. Hepatobiliary \& Pancreatic Diseases International 4, 604-608. 


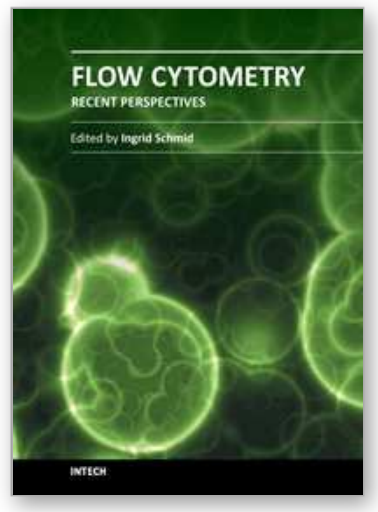

\section{Flow Cytometry - Recent Perspectives}

Edited by M.Sc. Ingrid Schmid

ISBN 978-953-51-0626-5

Hard cover, 500 pages

Publisher InTech

Published online 13, June, 2012

Published in print edition June, 2012

"Flow Cytometry - Recent Perspectives" is a compendium of comprehensive reviews and original scientific papers. The contents illustrate the constantly evolving application of flow cytometry to a multitude of scientific fields and technologies as well as its broad use as demonstrated by the international composition of the contributing author group. The book focuses on the utilization of the technology in basic sciences and covers such diverse areas as marine and plant biology, microbiology, immunology, and biotechnology. It is hoped that it will give novices a valuable introduction to the field, but will also provide experienced flow cytometrists with novel insights and a better understanding of the subject.

\section{How to reference}

In order to correctly reference this scholarly work, feel free to copy and paste the following:

Jai-Sing Yang, Yun-Peng Chao, Li-Jen Lin, Wen-Wen Huang, Jing-Gung Chung, Shu-Fen Peng, Chi-Cheng Lu, Jo-Hua Chiang, Shu-Ren Pai, Minoru Tsuzuki and Chung-Jen Chiang (2012). Ethanol Extract of Tripterygium wilfordii Hook. F. Induces G0/G1 Phase Arrest and Apoptosis in Human Leukemia HL-60 Cells Through c-myc and Mitochondria-Dependent Caspase Signaling Pathways, Flow Cytometry - Recent Perspectives, M.Sc. Ingrid Schmid (Ed.), ISBN: 978-953-51-0626-5, InTech, Available from: http://www.intechopen.com/books/flow-cytometry-recent-perspectives/ethanol-extract-of-tripterygium-wilfordiihook-f-induces-g0-g1-phase-arrest-and-apoptosis-in-hum

\section{INTECH}

open science | open minds

\author{
InTech Europe \\ University Campus STeP Ri \\ Slavka Krautzeka 83/A \\ 51000 Rijeka, Croatia \\ Phone: +385 (51) 770447 \\ Fax: +385 (51) 686166 \\ www.intechopen.com
}

\author{
InTech China \\ Unit 405, Office Block, Hotel Equatorial Shanghai \\ No.65, Yan An Road (West), Shanghai, 200040, China \\ 中国上海市延安西路65号上海国际贵都大饭店办公楼 405 单元 \\ Phone: +86-21-62489820 \\ Fax: $+86-21-62489821$
}


(C) 2012 The Author(s). Licensee IntechOpen. This is an open access article distributed under the terms of the Creative Commons Attribution 3.0 License, which permits unrestricted use, distribution, and reproduction in any medium, provided the original work is properly cited. 